\title{
The Role of Urban Agriculture in Improving the Livelihood of the Urban Poor and the Challenges: The Case of Hawassa City Administration, SNNPRS, Ethiopia
}

\author{
Mahteme Feleke Debela \\ Lecturer in the School of Governance and Development Studies, Hawassa University \\ Akalewold Fedilu Mohammed \\ Lecturer in the School of Governance and Development Studies, Hawassa University
}

\begin{abstract}
This study was conducted in Hawassa City with the main objective of assessing the role that urban agriculture plays in improving the livelihood of the urban poor and the challenges. It focused on three forms of urban agricultural activities namely bio-intensive gardening, backyard poultry keeping, and sheep rearing and fattening. The study employed a descriptive survey method which is supported by qualitative data. The results of the study revealed that urban agriculture has a very positive role in changing the livelihood of the urban poor for the better. It has enabled $76 \%$ of the respondents to obtain additional income, while serving $51.4 \%$ as a food source, and creating employment opportunity for $29 \%$. The major challenges to urban agriculture in Hawassa include lack of credit services, absence of technology to support the economic activity, lack of feed, treatment and input, and problems related to easy market access and storage places.
\end{abstract}

Keywords: Urban Poverty, Urban Agriculture, Livelihood, Challenges, Hawassa City

DOI: $10.7176 / \mathrm{JESD} / 11-1-01$

Publication date: January $31^{\text {st }} 2020$

\section{Introduction}

The world is being urbanized at a great speed. By the end of $2050,60 \%$ of the world's population is expected to be living in urban areas (Game and Primus, 2015: 1). This will be very likely for Africa as well, in which Ethiopia too is going to be part of the process. With this increase in the number of people living in urban areas, the level of urban poverty is also going to increase significantly.

Africa along with the other developing world is subject to this problem of urban poverty. By 2000 , the continent has shown a $37.9 \%$ urbanization rate which in 2015 was expected to reach $46.5 \%$, and in 2030 it is expected to further increase to $56.2 \%$ (Meheret, 2003: 17). This rapid urbanization has been followed by a massive increase in the level of urban poverty. Consequently studies show that most of the poorest African states have more than half of their urban population below the poverty line (Meheret, 2003: 18).

Ethiopia as one of the least developed states in the world is not a predominantly urbanized nation. Rather, the majority of the population of the country resides in rural areas and is engaged in agricultural activities (80-85\% of the population is employed in agriculture). Agriculture contributes to $40 \%$ of the total GDP. Crop production takes the largest share of the output of agricultural production making for $60 \%$, with livestock accounting for $27 \%$, and other areas contributing to the remaining 13\% (Atsbaha, 2010: 10).

According to a data released by the World Bank, only $19 \%$ of the Ethiopian population settles in urban areas. This number compared to other countries can be said to be at a very minimal stage. In spite of this fact, urbanization is expanding at a 4.3\% per annum (Mpofu, 2013: 53). And with this, urban poverty has become predominant. For example, the percentage of urban poor which was $11 \%$ in the year 2000 has increased to $14 \%$ (3.2 million) after a decade or in 2011. (World Bank, 2015: 107)

As a result, addressing the issue of urban poverty in Ethiopia has become an important aspect of development policy of the country. One of such mechanisms to be used by many developing states to fight urban poverty is the introduction of urban agriculture. Urban agriculture (UA) involves the production, processing and distribution of both food and non-food products within urban or peri-urban areas. It is mainly concerned with food production for household consumption and income generation (Mougeot, 2000: 15). These two are of major importance in promoting the livelihood of the urban poor because a greater portion (60 to 80\%) of their income is spent on food (Egbuna, 2008: 2).

Though it has only been a few years older than five decades, Hawassa is one of the Ethiopian cities witnessing fast urbanization today. This could be attributed to a number of factors. But above all, the city is the capital of SNNPR, Sidama Zone Administration and Hawassa Zuria Woreda Administration; these factors have highly contributed to the rapid population growth and expansion of the City. It is also observable that emerging parallel with the rapid growth of Hawassa City is urban poverty (Zeleke and Serkalem, 2006).

As a result, the practice of urban agriculture is introduced in an intensive manner within the city. Both the 
City's Agricultural Office and different NGOs are involved in the promotion of this activity to help the urban poor in the course of their endeavor to improving their livelihood.

However, the true effect that urban agriculture creates upon the lives of the urban poor remains unevaluated in the city. This study therefore, was set out to examine whether the practice brings major livelihood improvements to the poor dwellers of the city as per the anticipation of both of the government and the NGOs engaged in the activity. In line with this, it was also found important to identify what major factors contribute to its success or failure; what needs to be done to further promote the practice and combat its challenges.

\section{Review of Related Literature}

\subsection{Urban Poverty}

Looking at the trends of the world, with rapid urbanization, speedy urban poverty also takes place. Similarly, in Africa too rappid urbanization is followed by urban poverty; especially Sub-Sharan African states host the highest levels of urban poverty in the world. More than 50 percent of the urban poulation in the poorest countires lives below the poverty line (UN-HABITAT, 2008: 70). The report of FAO (2012: 13) by using a 'US\$ 1 per day' as the evaluation line, reduces this number by claiming that an estimated of 43 percent of the Sub-Saharan Africans fall under poverty. The worst form of urban poverty is manifested in the prevalence of slums which in the case of Africa, hosts around 52 percnet of the continent's urban population (Ibid).

In the case of Ethiopia as well, the same rapid urbanization is prevalent. Ethiopia has more than 900 cities which can be claimed to be 'urban'. The population residing in these urban areas is constantly increasing at a 4.3 percent per annum each year. A decade ago in 2006, the Package for Towns, Industy and Urban Development has estimated the number of urban dwellers to be around 12 million (FDRE-Job and Urban Development Ministry, 2006: 5-6).

The urban poor are hence people who obtain low and insecure income which in turn leaves them at a worse position in life as they will be subjected to malnutrition and diseases (FAO, 2012: 16-17). It is claimed that 9 out of 10 African urban workers are engaged in informal sectors where they work for long hours and get very low incomes without secure work contracts, social protection, or benefits (Ibid).

In the case of Ethiopia, thought only around 19 percent of the population resides in urban areas, the urban areas are places where unemployment, weak infrastructural setups, poor housing conditions, and slum areas are rampant. As a result, in the urbans of Ethiopia, poverty and unemployment are widely observed (FDRE-Job and Urban Development Ministry, 2006: 6).

Hence, in places where urban poverty is seen to supress the livelihood of urban dwellers, the practice of urban agriculture is considered to solve the problemsof such poor urban population. This is mainly because urban agriculture is a good source of nutritional food for the urban poor who are victims to malnutrition(Egbuna, 2008: 11).

\subsection{Urban Agriculture}

There happens to be no general consensus about the exact definition of Urban Agriculture among scholars and as a result it has been defined in different ways (Arku et al., 2012: 2). But all revolve around some central concepts which could be summed as location, nature of the activity, and the reason behind the practice.

The first of such concepts is regarding the location of the practice: urban agriculture is practiced within and outskirt of cities (Mireri et al.,2006: 3). Deelstra and Girardet (2004) in Tewodros (2007: 6), also support this by stating that it is a practice done mainly in public open space within or fringe of cities. Game and Primus (2015: 1) similarly claim that urban agricultre is an activity located in close proximity to populous regions that may be small or large areas within or around cities.

The other concept that is associated with defining the practice of urban agriculture is the nature of the agricultural activities. Mireri et al (2006: 3) considers any kind of crop or livestock production and agroforestry or fuel wood production to constitute the practice of urban agriculture. These authors also believe that the choice of what is to be produced is determined by different factors like culture, tradition, markets, water and rainfall supply, the climate of the area, the soil condition, and the level of exposure to the sun. Game and Primus (2015:1) explain the nature of urban agriculture as an activity which is concerned with food and other products that are obtained usually through plant cultivation and seldom through raising livestock; while Arku et al. (2012: 2) refers to any agricultural enterprise.

Concerning the third concept, the reason behind the engagement in the activities of urban agriculture, Arku et al. (2012: 3), states that it might range from home consumption to being sold at urban markets and export markets for pure profit generation purpose. And again the objective may range from supporting the household nutritional needs to income generation, and even to being a leisure activity (Ibid). Therefore, urban agriculture is the practice of agriculture in urban areas. 


\subsection{Advantages of Urban Agriculture}

The potential of urban agriculture in enhancing the situation of the urban citizens in general and the urban poor in particular is one of its major advantages (Bryld 2003 in Tewodros, 2007: 7). The UNDP (1996: 165) report supports this stand as it affirms that the practice of urban agriculture results in social equity by improving the health and productivity of the poor as a result providing them with the opportunity to earn additional income. And according to Mougeot (2000: 29) and (Arku et al., 2012: 1) the first of such advantages is associated with nutritional benefits. Through practicing urban agriculture, the urban poor get a greater access to variety of affordable and nutritious food. The urban poor spend around 50 to $70 \%$ of their income for purchasing food and yet cannot buy enough food for their own consumption. Practicing urban agriculture reduces this expenditure that poor households spend on food items and as a result increase the household savings which can be spent on other basic needs. (Bryceson and Potts 2005 in Tewodros, 2007: 7); Mougeot, 2000: 29)

Urban agriculture also generates supplemental or principal income for those who choose to sell the agricultural products. This in other words means an increased availability of agricultural products in urban markets. Additionally, the costs of the products will relatively be lower than the products coming from the rural areas. Hence, urban agriculture can moderate market price and as well serve fresher agricultural outputs to consumersthis is what Mougeot (2000: 31) identifies as community welfare and what (Arku et al., 2012: 1) identify as direct and indirect contribution to livelihood and various aspects of the urban economy as a whole.

Another benefit associated with urban agriculture is its capacity to result in environmental advantages. In addition to creating beautiful scenarios and landscapes, and improved microclimate and nutrient recycling, it is also favored for its ability to turn urban wastes into food and jobs, while also creating an improved living environment, better public health, energy savings, natural resources savings, land and water savings and urban waste management cost reductions (Smit and Nasr, 1992: 152).

\subsection{Challenges to Urban Agriculture}

Until two decades ago practicing any form of agricultural activity within the boundaries of urban centers states was made illegal in most of the African as a result of laws which date back to colonial times (Foeken et al., 2004: 3). Foeken further stated that urban farmers face challenges like uncertainty regarding land tenure, theft of crops or animals, lack of capital and inputs, threats of eviction and the possible destruction of crops. Giving a better explanation to the challenges, Smit et al. (A) (2001:1) classifies the challenges in to five categories as:

- Socio-cultural biases and institutional challenges;

- Challenges to access resources, inputs, and services;

- Risks associated to city farming;

- Post-production challenges in processing and marketing; and

- Organizational constraints

The sociocultural biases and institutional constraints usually emanate from misconceptions about aesthetics, efficiency, hygiene, and modernity in general. Policies, laws and regulations tend to institutionalize these biases (Smit et al. (A), 2001: 1). The challenges associated to access to resources, inputs and services include the problems associated with water sources for irrigation in towns. The lack of access to farming inputs like seeds, fertilizer, pesticides, equipment, feed, medicine and the like are the other constraints hampering the practice of urban agriculture in the second category. The challenge associated with accessing services for getting products to market on time, getting different technologies that promote the field also makes up this second category of challenge. The lack of trainings and formal education in the field accompanied by lack to credit access further complement the challenges (ibid: 11, 13, and 17).

In post-production challenges, Smit et al. (2001: 18-20) identifies the following as urban agriculture challenges: inadequate processing, storage, pacing, distribution, and marketing facilities. The organizational constraints amount to the lack of organization among the urban agriculturists themselves; especially in the case of low-income practitioners (ibid: 21 )

\section{Materials and Methods}

\subsection{Study area}

This study was conducted in Hawassa City. The City has eight Sub-Cities. Of these eight, two (Mehal Ketema Sub-City and Bahil Adarash Sub-City) are identified by the city administration as comprising of predominantly poor societies. Again, these two sub-cities have purposively been selected for the study. This is because within them, the sub-cities host kebeles that are inhabited by people practicing urban agriculture.

\subsection{Research Design}

A cross sectional study which employs both qualitative and quantitative research designs was used. To effectively capture the measurable and quantifiable aspects in the level of change that comes as a result of practicing urban agriculture in a household, and as well to compare between the three different urban agricultural practices (bio 
intensive gardening, backyard poultry, and sheep rearing and fattening) qualitative study has been employed.

\subsection{Sampling Technique}

The selection of Hawassa city has been purposive. This is due to the fact that the city is one of the most urbanized cities in the country, and also because it hosts neighborhoods that are subjected to urban poverty. Again, two kebeles from Mehal Ketema Sub-City (Addis Abeba Kebele and Leku Kebele) and one Kebele from Bahil adaradsh Sub-City (Andinet Kebele) have been purposively selected. These three kebeles are kebeles where poverty is most predominant and urban agriculture is practiced with an assistances extended to the people from a local NGO called JeCCDO starting from 2012 for the past five years.

As this study is concerned with examining the benefit/assistance that urban agriculture has to the livelihood of the urban poor, it has been found important to examine households that have been given extensive trainings and the necessary inputs required for the practice. The selected households in the three kebeles mentioned above have got these trainings and inputs from JeCCDO.

Finally, the sample population was selected by using simple random sampling technique after stratifying the urban agriculture practice into three forms which include bio-intensive gardening, backyard poultry keeping, and small animals rearing (sheep rearing and fattening).

\subsection{Sample Size Determination}

To determine the sample size for this study, 434 households who obtained trainings and assistance from JeCCDO for their urban agricultural practices on three forms of urban agricultural practices (Bio-intensive gardening, Backyard poultry keeping, and Sheep rearing and fattening) in the three kebeles for over the past five years have been identified as the total population size. To determine the total sample size, Yemane (1967) formula was used. Accordingly, a sample size of 138 households was identified, and determined as sample population.

The size of the sample that is included in this study is calculated as:

$\mathrm{n}=\mathrm{N} / 1+\mathrm{N}(\mathrm{e})^{2}$

$\mathrm{n}=434 / 1+434(0.07)^{2}=138$

Where, N-total population/sampling frame of the study,

e- Sampling error amounting to $7 \%$, i.e, 0.07

In determining the exact number of sample to be taken from each of the three strata equal number of sample size has been allocated for each stratum in order to make a fair comparison across the three activities. Hence, by dividing the total sample size of 138 in to three equal parts to make up each of the three stratums, 46 households have been chosen from each stratum.

To identify the number of sample households to be taken from each Kebele and forms of urban agricultural practice, probability proportional sampling was used, as shown below.

Where

$$
\text { ni }=\frac{n(N i)}{N}
$$

$n i$ is a sample to be taken from each stratum,

$n$ is a total sample size to be taken,

$\mathrm{Ni}$ is the population of each stratum, and

$N$ is the total population.

The following sample size was taken from each kebele and forms of urban agricultural practices

(See Table 1).

Table 1. Population and sample distribution over the three kebeles

\begin{tabular}{|c|c|c|c|c|c|c|c|c|}
\hline \multirow[t]{2}{*}{$\begin{array}{l}\text { Types of } \text { Urban } \\
\text { Agricultural practice }\end{array}$} & \multicolumn{3}{|c|}{$\begin{array}{l}\text { Total No. of Beneficiaries in } \\
\text { each Kebele }\end{array}$} & \multirow[t]{2}{*}{ Sum } & \multicolumn{3}{|c|}{$\begin{array}{l}\text { Total No. of selected samples in } \\
\text { each Kebele }\end{array}$} & \multirow[t]{2}{*}{ Sum } \\
\hline & $\begin{array}{l}\text { Andinet } \\
\text { Kebele }\end{array}$ & $\begin{array}{l}\text { Addis } \\
\text { Abeba } \\
\text { Kebele }\end{array}$ & $\begin{array}{l}\text { Leku } \\
\text { Kebele }\end{array}$ & & $\begin{array}{l}\text { Andinet } \\
\text { Kebele }\end{array}$ & $\begin{array}{l}\text { Addis } \\
\text { Abeba } \\
\text { Kebele }\end{array}$ & $\begin{array}{l}\text { Leku } \\
\text { Kebele }\end{array}$ & \\
\hline $\begin{array}{l}\text { Sheep rearing and } \\
\text { fattening }\end{array}$ & 36 & 45 & 61 & 142 & 12 & 14 & 20 & 46 \\
\hline $\begin{array}{l}\text { Backyard } \\
\text { keeping }\end{array}$ & 49 & 49 & 56 & 154 & 15 & 15 & 16 & 46 \\
\hline Bio Intensive Gardening & 10 & 55 & 73 & 138 & 4 & 18 & 24 & 46 \\
\hline Total UA Beneficiaries & 95 & 149 & 190 & 434 & 31 & 47 & 60 & 138 \\
\hline
\end{tabular}

\subsection{Data type, source, collection tools and analysis}

Both quantitative and qualitative data were used to analyze the situation. Moreover, both primary and secondary data sources have been used in the study. Primary data was gathered in the form of survey questionnaire, interview and also personal observation. Secondary data has also been collected from books, journals, websites and different 
publications to complement the study.

Finally, data collected through the above mentioned methods was analyzed and interpreted according to their nature. To facilitate the analysis, computer software program (Statistical Package for Social Science/ SPSS Version 20) has been employed for the quantitative data; while the qualitative data has been paraphrased and analyzed in a meaningful way. The results of the study have been presented in descriptions, tables, graphs and pie-charts.

\section{Result and Discussion}

\subsection{Background of the Respondents}

The respondents are the heads of their respective households. The sex distribution of these household heads in the study kebeles has somehow proportional nature. Out of the 138 respondents, 67 were male while 71 were female. Percentage wise, this makes the male headed households $48.6 \%$ and the females $51.4 \%$. This shows that both male and female actors are almost equally engaged in the practice of urban agriculture in the city. This finding is contrary to what has been mentioned in FAO (2012: 20) claiming that women are to a greater extent, more engaged in the field of urban agriculture than that of men. Yes women are still found to engage more in the field, but the differnce across the sexes is quite minimal.

With two respondents choosing not to disclose their age, the age of the remaining respondents ranges from a minimum of 28 years old to a maximum of 80 years old. Classifying the age range in to six (see Fig. 1), the majority of the respondents fall within the age group of 44-50.

Fig 1. Bar graph of the Age of Respondents classified into six age groups

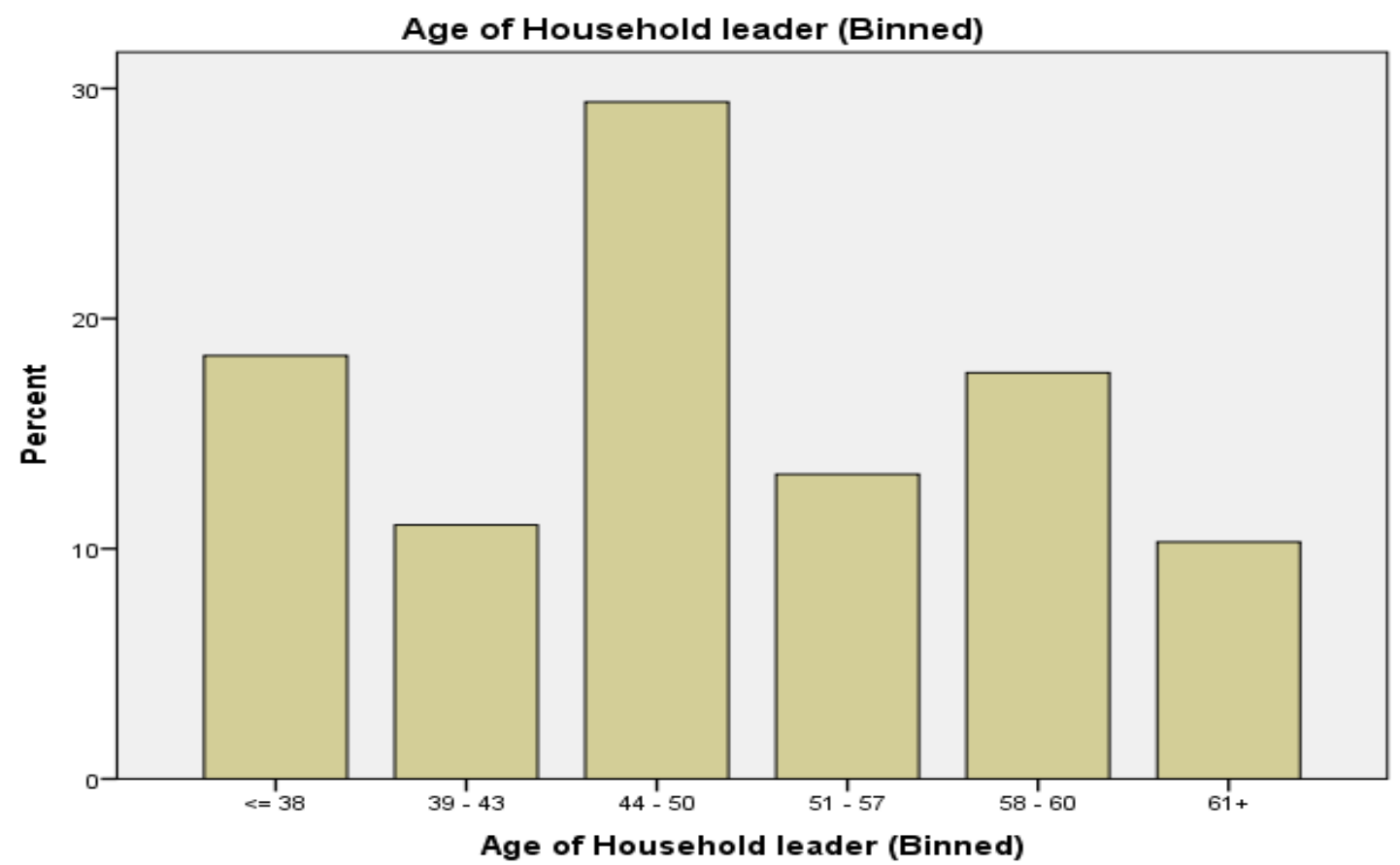

Source: Field Survey, 2016

Concerning family size of respondents, $57.2 \%$ of the households have a family size of $1-5$ individuals. The remaining $40.9 \%$ have $6-10$ members while $1.5 \%$ of the households have a family size of larger than 10 members. Regarding their residents, $53.6 \%$ live in Kebele homes (homes rented from the government), while $41.3 \%$ live in their personal homes. The remaining $5.1 \%$ live in homes rented from individual landlords.

Put in ascending order, the major sources of income for $87 \%$ of the households head are informal income generating activities (like small business activities run from home), pension, and income from a formal form of employment. Moreover, $8 \%$ of the respondents depend on remittance while the remaining $5 \%$ of the respondents have multiple sources of income (i.e. a combination of any of the above mentioned four sources: income from formal employment, pension, remittance, and other informal income generating activities. 
Fig 2. Pie Chart showing the source of the income of respondents in percentage

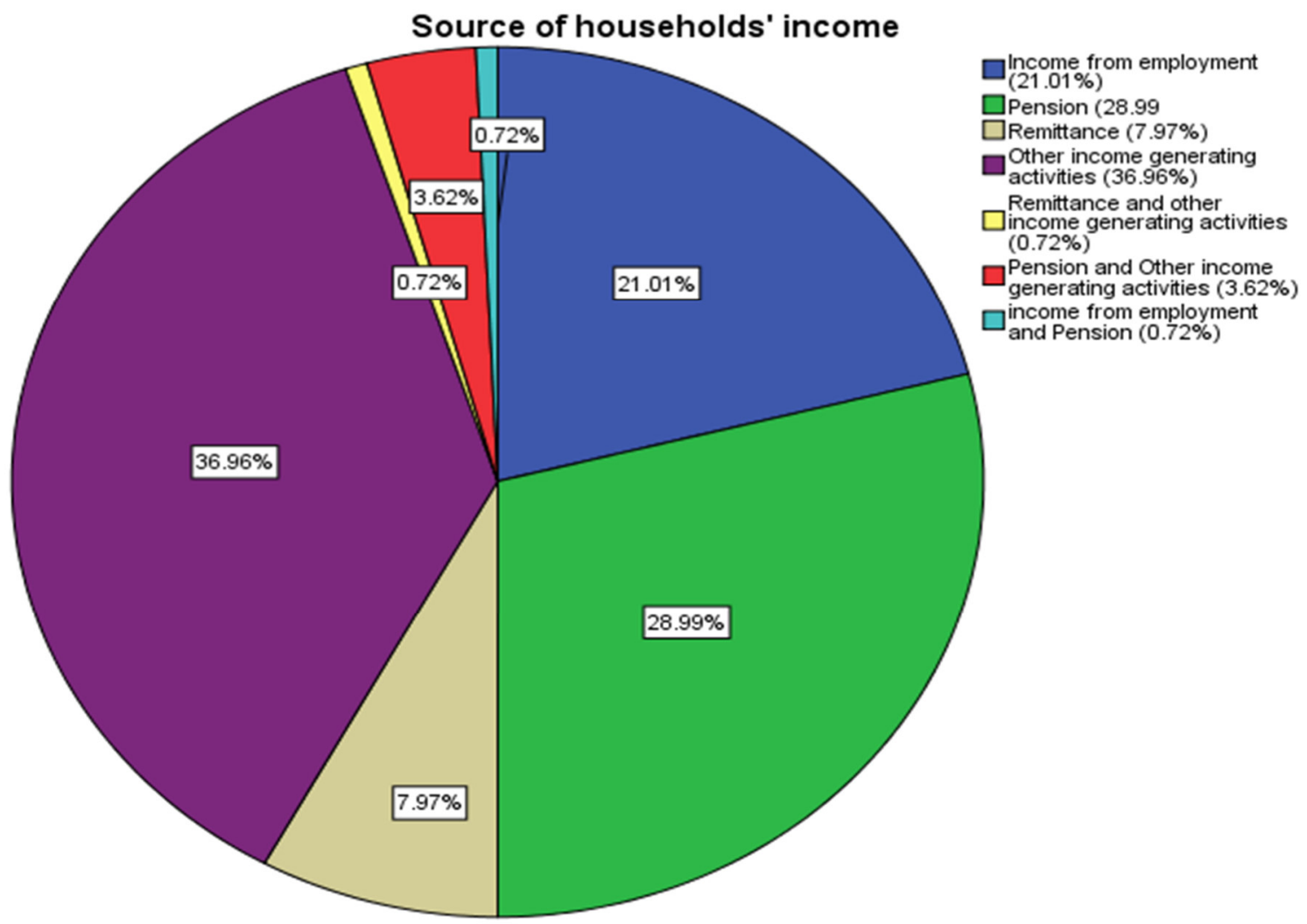

Source: Field Survey, 2016

\subsection{Contribution of Urban Agriculture to Livelihood Improvement of Respondents}

To examine the positive outcomes that households derive out of the practice of urban agriculture, three forms of measuring tools were used. The first is regarding the contribution of the activity as a direct food source to the practicing household, the second is regarding the capacity of the activity to generate additional income to the household, and the third is to identify whether the activity has served as an employment opportunity to any unemployed member of the household. To this effect, the study has identified that except for the $15.2 \%$ of the respondents who claimed not to have derived any of the three forms of benefit, the remaining $84.8 \%$ of them have attained one or more of the three forms of benefit (see Table 2).

Table 2. Types of benefits derived by respondents

\begin{tabular}{|l|l|l|l|}
\hline No. & Types of Benefits Derived by Practitioners & $\begin{array}{l}\text { No. of Respondents } \\
\text { obtaining } \\
\text { out of a total of 138 } \\
\text { Respondents }\end{array}$ & $\begin{array}{l}\text { Percentage of } \\
\text { the } \\
\text { respondents }\end{array}$ \\
\hline 1 & Serving as a Food Source to the household only & 10 & $7.2 \%$ \\
\hline 2 & Generating Additional Income to the household only & 28 & $20.3 \%$ \\
\hline 3 & Creating an Employment Opportunity for an & 1 & $0.7 \%$ \\
\hline 4 & $\begin{array}{l}\text { Serving as a Food Source for the household, Generating } \\
\text { Additional Income, and Creating } \\
\text { Employment Opportunity }\end{array}$ & 21 & $15.2 \%$ \\
\hline 5 & $\begin{array}{l}\text { Generating Additional Income and Creating } \\
\text { Employment Opportunity }\end{array}$ & 17 & $12.3 \%$ \\
\hline 6 & $\begin{array}{l}\text { Serving as a Food Source and Generating } \\
\text { Additional Income to the household }\end{array}$ & 39 & $28.3 \%$ \\
\hline 7 & $\begin{array}{l}\text { Serving as a Food Source and Creating } \\
\text { Employment Opportunity }\end{array}$ & 1 & $0.7 \%$ \\
\hline 8 & No form of benefit obtained from the activity & 21 & $15.2 \%$ \\
\hline & Total & $\mathbf{1 3 8}$ & $\mathbf{1 0 0 \%}$ \\
\hline
\end{tabular}

Source: Field Survey, 2016 


\subsection{Generating Additional Income to the Household}

The most important benefit of urban agriculture in the study kebeles is additional income generation. This is so because more than $3 / 4^{\text {th }}(76 \%)$ of the respondents have admitted urban agriculture to be their source of additional income. This finding goes in line with Salau and Attah (2012: 25) who said that $75.56 \%$ of their respondents got their income in the same activity. Others like Arku et al. (2012: 6-10), Onlyango (2010: 129), Tewodros (2007: 29) and Gebremedhin and Bihon (2009: 27-29) have also similar findings about the contribution of urban agriculture as a source of additional income.

To analyze by how much that the households have experienced an increase in income, they were asked to range both their previous monthly income (income prior to the time the household used to undertake urban agriculture), and their current monthly income. And the following has been obtained by the study. The income level of most of the households in fact shows increment. As such, 50.7\% of the respondents used to obtain an amount less than ETB 400 prior to their engagement in the activity. But, this amount has significantly improved later. And now, it is only $36.2 \%$ who have said to obtain less than ETB 400 . The percentage of respondents obtaining between $401-700$ increased from $36.2 \%$ to $37 \%$. Similarly, the amount between ETB $701-1000$ that referred previously to $12.3 \%$ of the respondents rose currently to $22.5 \%$. This increase in monthly income may not be the outcome of the urban agricultural activity alone; but it can however support the finding stated above, which claims that practicing urban agriculture has served in generating additional income to the $76 \%$ of respondents.

Table 3. Income comparison of households in pre and post Urban Agriculture practices

\begin{tabular}{|c|c|c|}
\hline \multirow[b]{2}{*}{ Monthly Income Range in Birr } & \multicolumn{2}{|c|}{ Percentage of Households falling in a given income range } \\
\hline & 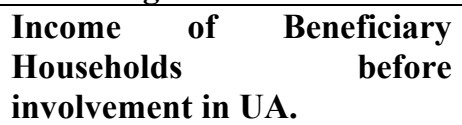 & $\begin{array}{l}\text { Income of Beneficiary } \\
\text { Households after involvement } \\
\text { in UA. }\end{array}$ \\
\hline 200-400 Birr & $50.7 \%$ & $36.2 \%$ \\
\hline 401-700 Birr & $36.2 \%$ & $37 \%$ \\
\hline 701-1000 Birr & $12.3 \%$ & $22.5 \%$ \\
\hline More than 1000 Birr & $0.7 \%$ & $4.3 \%$ \\
\hline Total & $100 \%$ & $100 \%$ \\
\hline
\end{tabular}

Source: Field Survey, 2016

Income is one of the basic livelihood assets that directly impact the livelihood advancement of households. More income means more dispensable income, which in turn means more food security, more saving, more investments (investments on health, education, and employment condition of household members). Therefore, this directly implies that the vulnerability context of the households is somehow reduced and that the well-being of households is improved.

\subsection{Serving as a Food Source to the Household}

The benefit that is strongly felt next to additional income is using the agricultural outputs for home consumption to meet the food needs of the household. Accordingly, 51.44\% of the respondents claimed that they have benefited this way. To crosscheck the validity, a similar question in different format was asked to the respondents. That is, whether they consume the agricultural output or not. Thus, $52.2 \%$ claimed that they do consume some of the products at home. This proves that over half of the sample population consumes the agricultural product at home. This finding confirms to previous studies like Salau and Attah $(2012: 25)$ that have showed that 55.56\% of the respondents in their study have obtained household feeding benefits. The works of Kekana (2006: 51-52), Onyango (2010: 129), Arku et al. (2012: 17), and Mpofu (2013: 54-55) also indicated similar findings about the contribution of urban agriculture as a food source to the urban poor.

The study has found out that this form of benefit supports households in two terms. First, it directly reduces the food expenses of the households; as a result contributes in increasing the dispensable income of the household. Second, it provides households with nutritious food for a dramatically low price. This second form of support is confirmed by one of the key informants who mentioned that the eggs that she obtains from practicing urban agriculture have enabled her to feed her family. To quote her in this regard of argument; "Previously, we were not able to consume eggs due to the high price in the markets. Now, things have changed and my family gets eggs every day" (Interview, April 2016). The contribution of nutritious food to the health of individuals is no secret. No doubt, therefore, that the benefit greatly boosts the human capital of a concerned household.

\subsection{Creating Employment Opportunity for an Unemployed Household Member}

The third form of benefit supporting the livelihood of the practitioners identified by this study is employment creation. Accordingly, only $28.98 \%$ of the respondents benefit from this opportunity. Employment creation is not a benefit which is as significant as the other two forms of benefits discussed so far. But still, this also is a major benefit contributing to the livelihood improvement of households.

Employment opportunity for a household member who previously was unemployed is followed by additional 
income generation for the household; which as discussed above is the key behind livelihood improvement. This finding perfectly supports a study conducted by Salau and Attah in Nigeria. In their study Salau and Attah (2012:25) found that $28.89 \%$ of the respondents were benefiting from this opportunity.

As a conclusion to this part, with additional income generation, contributing to the food needs of the household, and by creating an employment opportunity, urban agriculture is reducing the vulnerability and improving the well-being of the poor households under the study. In other words, urban agriculture as a livelihood strategy is proved to be a successful mechanism to promote the livelihood of the urban poor who are engaged in it. This conclusion is in line with Mogeut (2000) in Tewodros (2007:2).

Table 4. Number of respondents benefiting from among the three forms of benefits

\begin{tabular}{|c|c|c|c|c|}
\hline No. & Type of Benefit & $\begin{array}{l}\text { Total Number of } \\
\text { respondents }\end{array}$ & $\begin{array}{l}\text { Number } \\
\text { Respondents } \\
\text { benefited }\end{array}$ & $\begin{array}{l}\text { Total Number of } \\
\text { respondents }\end{array}$ \\
\hline 1 & $\begin{array}{l}\text { Serving as a Food Source to the } \\
\text { household }\end{array}$ & 138 & 71 & $51.44 \%$ \\
\hline 2 & $\begin{array}{l}\text { Generating Additional Income to } \\
\text { the household }\end{array}$ & 138 & 105 & $76 \%$ \\
\hline 3 & $\begin{array}{l}\text { Creating an Employment } \\
\text { Opportunity for an unemployed } \\
\text { member of the household }\end{array}$ & 138 & 40 & $28.98 \%$ \\
\hline
\end{tabular}

Source: Field Survey, 2016

\subsection{Comparison across Different forms of Urban Agriculture}

Three forms of urban agriculture; bio intensive gardening, backyard poultry keeping, and sheep fattening and rearing have been studied in this work. Each sector has been represented equally in the sample population as 46 households from each activity have been examined for the purpose of the study. As it is depicted in Table 5, it can be understood that practitioners engaged in all the three activities, more than $3 / 4^{\text {th }}$ of the respondents $(78 \%)$ believed to have been successful in their respective fields of engagement. However, comparing the three sectors, it can be seen that practitioners engaged in Sheep rearing and fattening believe to be more successful than those in the remaining two strata. Again comparing the remaining two, backyard poultry keepers have been more associated with success than bio-intensive gardeners.

Looking at the percentage of respondents claiming to have benefited nothing out of the activity that they have engaged in, larger numbers of respondents are form the respondents engaged in bio-intensive gardening, this activity is found to be of a lesser benefit to practitioners while compared to the remaining two strata. Comparing the remaining two, the respondents engaged in backyard poultry keeping to a greater extent claimed not to have benefited from the activity. Just like the conclusion reached at about the attitude of success by respondents, here too sheep rearing and fattening stands out while compared to the remaining two strata. And from among biointensive gardening and backyard poultry keeping, the latter is found to be more advantageous to the respondents. Table 5. Comparison of successful practitioners among the three strata of Urban Agriculture

\begin{tabular}{|l|l|l|}
\hline $\begin{array}{l}\text { Type of Urban Agricultural } \\
\text { Activity }\end{array}$ & $\begin{array}{l}\text { Percentage of respondents } \\
\text { believing to have been Successful } \\
\text { at different levels }\end{array}$ & $\begin{array}{l}\text { Percentage of Respondents } \\
\text { claiming to obtain no form of } \\
\text { benefit }\end{array}$ \\
\hline Bio-intensive Gardening & $78.3 \%$ & $17.4 \%$ \\
\hline Backyard Poultry Keeping & $80.5 \%$ & $15.2 \%$ \\
\hline Sheep Rearing and Fattening & $86.9 \%$ & $13 \%$ \\
\hline
\end{tabular}

Source: Field Survey, 2016

\subsection{The challenges}

\subsubsection{Challenges Faced by Respondents}

To examine the major challenges and opportunities that the practitioners face while engaged in the respective urban agricultural activities, a list of challenges and opportunities identified by former studies have been provided to them. To this effect, the challenges identified by Smit et al. (A) (2001:1) have been used in this study. 


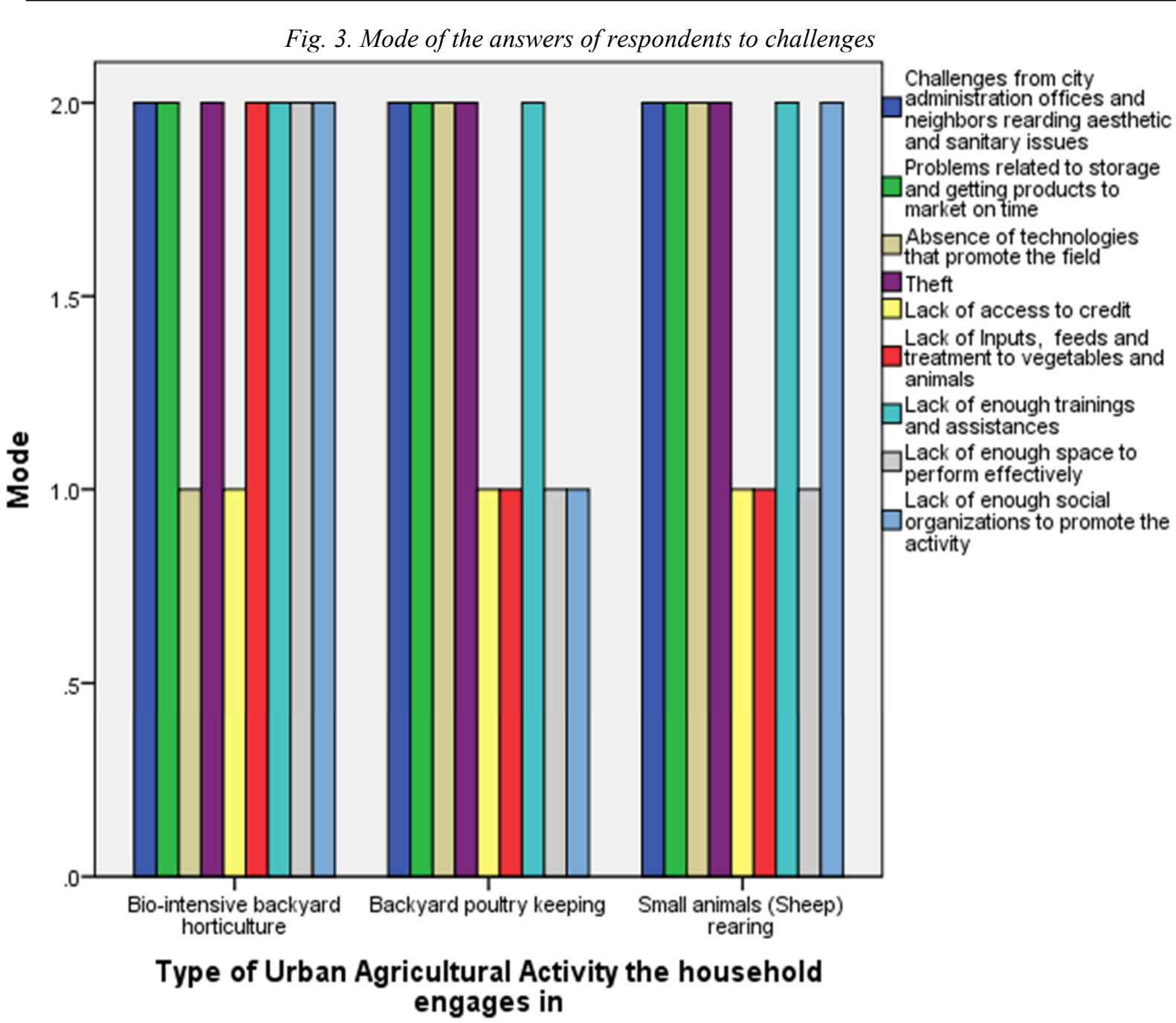

Source: Field Survey, 2016

4.7.2. Challenge associated with complaints that arise from city administration offices and neighbors regarding aesthetic and sanitary issues

As it can be seen from the graph, regarding the first challenge, which is associated with complaints that might arise from city administration offices and neighbors regarding aesthetic and sanitary issues, in all three strata, most of the respondents have claimed that they have not faced such challenges. But, this does not mean that all respondents didn't face such a challenge since it has been identified by the study that 21(15.2\%) respondents out of the total sample population in the three forms of agricultural activities have mentioned that they have faced this challenge. Despite, this challenge is not that much of a serious nature hampering the activities of urban agricultural practitioners in all the three strata.

\subsubsection{Problem related to storage and getting products to market on time}

The bar graph shows that this problem is not faced by most of the practitioners engaged in all the three strata. Out of the 138 respondents, only 33 amounting to $23.9 \%$ have mentioned this as a challenge while the remaining $76.1 \%$ is free of the challenge. What can be inferred from the above paragraph is that problems related to 'storage of products and getting the products to market while they are still in good form', though it is not such a serious challenge for the activities, however it is mainly associated with backyard poultry keeping and sheep rearing and fattening.

\subsubsection{Absence of technologies that promote the urban agriculture}

Generally, a closer to half $(47.8 \%)$ of the respondents have mentioned that they have faced this challenge while a slightly greater half (52.2\%) has not identified it a major challenge to the practice of urban agriculture. Hence, though more than half of the respondents claimed not to have faced the challenge in the second two strata, the amount of respondents facing the problem however makes it an issue to be alarmed about. Therefore, even if biointensive gardening seems to be the one challenged most by the challenge, it is safe to conclude that the remaining two activities also suffer greatly from it. 


\subsubsection{Theft}

Theft is one of the major challenges associated with urban agriculture. In this study it has been found that theft in general is an issue to be concerned about as $27.5 \%$ of the respondents have mentioned it as a challenge. Consequently, though the percentage of population facing this challenge is less than the population who has not so far faced the problem, the challenge cannot be ignored especially in the case of backyard poultry keeping and sheep rearing and fattening.

\subsubsection{Lack of access to credit}

This problem is strongly felt in all three strata. More than half of the respondents have agreed that lack of access to credit is a great challenge. In general terms, $50.7 \%$ of the total respondents have faced this challenge. In the case of bio-intensive gardening $52.2 \%$ of the practitioners agreed that they have faced such challenges while in the remaining two strata, an equal amount of 50\% claimed to have faced the challenge. Therefore, lack of access to credit is a serious challenge that is faced by poor urban agriculture practitioners

\subsubsection{Lack of inputs, feeds and treatment to vegetables and animals}

This challenge is claimed to have been faced by $50.7 \%$ of the total respondents. But it should be noted that it is not strongly felt in the case of bio-intensive gardening. Only $6.5 \%$ of the respondents have mentioned this as a challenge. As identified by an interview held with one of the respondents, the main reason for this is that the agricultural inputs can easily be found at local stores for a reasonable price.

The story is different in the case of backyard poultry keeping and sheep rearing and fattening. Both activities suffer from this challenge. $76.1 \%$ of backyard poultry keepers and $69.6 \%$ of the respondents engaged in sheep rearing and fattening have faced this challenge. In fact, main cause behind the absence of success in these two strata is associated to this challenge. Especially as it is revealed in interview sessions with practitioners from these fields, the treatment for sheep and chicken is not easily accessible. And in the case of chicken, even where treatment is available from private veterinary stores; the effectiveness of the treatment is highly questionable.

\subsubsection{Lack of enough trainings and assistance}

From the total respondents, $29 \%$ of them have faced this challenge. However, comparing the three strata, it is more felt by poultry keepers and those engaged in sheep rearing and fattening activities as $43.5 \%$ and $32.6 \%$ of the respondents respectively claimed that had they obtained more assistance and trainings in the field, that they would have been more successful.

\subsubsection{Lack of enough space to perform effectively}

The urban poor usually reside in small and congested environment. Many of the respondents in the study (53.6\%) are living in homes rented from the government (kebele houses). These houses are small compounds with lots of houses, each house having a separate family. Thus, many of the respondents faced this challenge. Even those living in their personally owned houses have to rent out rooms to other people to generate additional income. This again takes up the space that they have in their compounds. This has been proved through the observations undertaken in the study kebeles.

As a result of this, $51.4 \%$ of the total respondents have faced this challenge. While separately examining the three strata, the study has identified that $37 \%$ of bio-intensive gardeners, $60.9 \%$ of poultry keepers and $56.5 \%$ of the respondents from sheep rearing and fattening face this challenge. This makes it an issue of serious concern.

\subsubsection{Lack of enough social organizations to promote the activity}

Social organizations solely created to support the activity of urban agriculture are widely found in Addis Abeba Kebele. Other social institutions which are created for other social purposes (like edir and ikub) at times tend to work with NGOs engaged in promoting the livelihood of the urban poor in the study kebeles.

From the total respondents, $47.8 \%$ claimed to suffer from this challenge. By examining the three strata separately, the study has identified that backyard poultry keeping is the activity which is more affected by it as $52.2 \%$ of the respondents stated that they have faced this challenge. In the case of the remaining two strata, the amount of respondents who have faced this challenge are less than $50 \%$; but still since $43.5 \%$ of bio-intensive gardeners and $47.8 \%$ of those engaged in sheep rearing and fattening have faced the challenge, it is not to be ignored.

\section{Conclusions}

This study had an overreaching objective of assessing the role that urban agriculture plays in improving the livelihood of the urban poor and the challenges. Accordingly, the findings of the study found out that except for 'human capital' most of the households are not endowed with the remaining four livelihood assets. In other words, natural capital, financial capital, physical capital and social capital of households are not much strong. However, primarily, practicing urban agriculture has enabled them to generate additional income to the household. Serving the practitioners as a good source of food is another direct benefit derived from practicing urban agriculture. Another important contribution that urban agriculture provided the respondents with is the creation of employment opportunities for unemployed household members. Therefore, it can safely be concluded that urban agriculture is a livelihood strategy which positively affects the livelihood of the urban poor in Hawassa City Administration. 
The other thing that the study set out to do is to assess the challenges in the process of practicing urban agriculture. To this effect, the study has found out that challenges like market access, absence of technologies supporting the activity, lack of inputs, feeds and treatment to vegetables and animals, lack of access to credit, absence of social institutions supporting the activity and prevalence of theft all affect the practice of urban agriculture by the poor, in Hawassa City Administration. In spite of these challenges however, urban agriculture is a great instrument to reduce urban poverty within cities. Hence, to improve these challenges and to further promote urban agriculture, Hawassa City Administration, the City's Agricultural Office and other stakeholders that are engaged in improving the livelihood of the urban poor and providing training should play their role to curb the challenges by facilitating a fair and easily accessible market opportunity for practitioners, promotion of technologies to support urban agriculture, providing trainings and assistances, and input which include feed and treatment for animals and vegetables, and making the practitioners part of a local saving and credit service institution to have access for credit.

\section{References}

Arku, G., Mkandawire, P., Aguda, N. and Kuuire, V. (2012). Africa's Quest for Food Security: What is the Role of Urban Agriculture? Zimbabwe: The African Capacity Building Foundation.

Atsbaha Gebre-Selassie. (2010). A Review of Ethiopian Agriculture: Roles, Policy and Small-scale Farming Systmes. Addis Ababa: KOPIN and Emmanuel Development Association.

Bryceson, D., \& Potts, D. (Eds.). (2005). African Urban Economies: viability, vitality or vitiation?. Springer.

Egbuna, N. E. (2008). Urban Agriculture: A strategy for poverty reduction in Nigeria. Monetary Policy Department Centeral Bank of Nigeria, 1-24.

FAO. (2012). Growing greener cities in Africa. Rome: Food and Agriculture Organization of the United Nations.

FDRE-Job and Urban Development Ministry. (2006). Towns, Industry and Urban Development Package . Addis Ababa, Ethiopia.

Foeken, D., Sofer, M., and Mlozi, M. (2004). Urban agriculture in Tanzania Isues of sustainabillity. The Ntherlands: African Studies Center.

Game, I. and Primus, R. (2015). Urban Agriculture. GSDR 2015 Brief Urban Agriculture. Secretariat of the United Nations.

Gebremedhin Yihdego and Bihon Kassa. (2009). Urban and Peri-Urban Ariculture: An Important Form of Land Use, Employment Opportunity and Food Supply in Meelle city and Enderta Woreda. Journal of the Drylands, Vol. 2(No. 1), 25-31.

Kekana, D. S. (2006). A Socio-economic analysis of urban agriculture: The Soshanguve project case study. Partial fulfilment of the requirements for the degree: Maister Institutional Agrariar in the Department of Agricultural Economics, Extension and Rural Development. Univeristy of Pretoria.

Meheret Ayenew. (2003). Urban Poverty and Urban Governance Institutions. In D. Rahmato (Ed.). Addis Ababa: Forum for Social Studies.

Mireri C., A. Kyessi, N Mushi and P. Atekyereza. (2006). Urban Agriculture in East Africa: Practice, Challenges and Opportunities. City Farmer: Canada's Office of Urban Agriculture.

Mougeot, L. J. (2000). Urban Agriculture: Definition, Presence, Potentials and Risks, and Policy challenges. Ottawa: International Development Research Center.

Mpofu, T. P. (2013). An evaluation of the performace of urban ariculture in Addis-Ababa City, Ethiopia. Research Journal of Agricultural and Environmental Manaement, Vol. 2(No. 2), 51-57.

Onyango, C. L. (2010). Urban and Peri-urban Agriculture as a Poverty Alleviation Strategy Among Low Income Households: The Case of Orange Farm, South Johannesburg. Thesis Paper Submitted in accordance with the requirmentsfor the degree of Masterof Arts in the Subject of Development Studies at the University of South Africa. South Africa: Unpublished.

Salau, E. S. and Attah, A. J. (2012). A Socio-Economic Analysis of Urban Agriculture in Nasarawa State, Nigeria. Patnsuk Journal, Vol. 8(No. 1), 17-29.

Smit, J. and Nasr, J. (1992). Urban Agriculture for Sustainable Cities: using wates and idle land and water bodies as resources. Environment and Unrbanization, Vol. 4(No. 2), 141-152.

Smit, J., Nasr, J., and Ratta, A. (A). (2001). Chapter 9: Constraints to Urban Agriculture. In J. N. Jac Smit, Urban Agriculture: Food, Jobs and Sustainable Cities (pp. 1-23). The Urban Agriculture Network, Inc.

Smit, J., Nasr, J. and Ratta, A. (B). (2001). Chapter 8: Problems Related to urban Agriculture. In J. N. Jac Smit, Urban Agriculture: Food, Jobs and Sustainable cities (pp. 1-32). The Urban Agriuclture Netowrk, Inc. .

Tewodros Firdissa Duressa. (2007). Livelihood Dependence on Urban Agriculture in Addis Ababa, Ethiopia. Department of International Enviironment and Development Studies: Noragric.

UNDP. (1996). Urban Agriculture: Food, Jobs and Sustainable Cities. Vol. 1. New York: United Nations Development Program One UN Plaza.

UN-HABITAT. (2008). State of the World's Cities 2008/2009 Harmonious cities. London: Earthscan. 
World Bank. (2015). Ethiopia Poverty Assessmentt. Addis Ababa: World Bank Group.

Zeleke Kebede and Serkalem Alemayehu. (2006). History of Hawassa (1952-1998 EC). Hawassa: Tony Printing. Yemane, M. (1967). Elemantary Sampling Theory, Printice-Hall Inc. Englewood Cliffs, New Jersey, USA. 